А. Ю. Игнатьев

Байкальский государственный университет, г. Иркутск, Российская Федераџия

Н. А. Брянская

Байкальский государственный университет, г. Иркутск, Российская Федерация

\title{
АНАЛИЗ РЫНКА АВТОСЕРВИСНЫХ УСЛУГ В ГОРОДЕ ЗИМА И ЗИМИНСКОМ РАЙОНЕ
}

\begin{abstract}
АННОТАЦИЯ. Подъем отечественного автомобилестроения, рост импорта иностранных автомобилей в нашей стране, увеличение потребности в их обслуживании и ремонте способствовало динамичному развитию рынка автосервисных услуг. Для предпринимателя, начинающего свой бизнес на данном рынке, актуальной является информация о тенденциях развития этого рынка, основных конкурентах, их слабых и сильных сторон. В статье исследуется рынок автосервисных услуг в городе Зима и Зиминском районе. Обоснование основных направлений развития рынка автосервисных услуг производится на основе данных взятых в РЭО ГИБДД ОВД по г. Зима и Зиминскому район, данных, которые размещены в свободном доступе на официальном сайте федеральной налоговой службы в разделе о едином реестре субъектов малого предпринимательства, собранных А. Ю. Игнатьевым. Авторами была проанализирована деятельность большинства автосервисных компаний, находящихся на исследуемой территории. В результате анализа были выявлены четыре основные компании, действующие на рынке. Дальнейший анализ позволил выявить их сильные и слабые стороны конкурентов и определить лидера этого рынка.
\end{abstract}

ключЕвыЕ словА. Автосервисные компании; автосервисные услуги; автосервис; конкуренты; анализ; рынок.

ИНФОРМАЦИЯ О СТАТЬЕ. Дата Поступления 3 июля 2017 г.; дата принятия к печати 11 октября 2017 г.; дата онлайн-размещения 25 октября 2017 г.

A. Yu. Ignatyev Baikal State University, Irkutsk, Russian Federation

N. A. Bryanskaya Baikal State University, Irkutsk, Russian Federation

\section{ANALYSIS OF CAR-CARE SERVICE MARKET IN THE TOWN OF ZIMA AND ZIMA DISTRICT}

\begin{abstract}
The rise of domestic car industry, the growth of foreign car import in our country, the increase in need for their maintenance and repair has contributed to dynamic development of the car-care service market. The information concerning the development trends of this market, the main competitors, their weak and strong points is relevant for an entrepreneur who starts business at this market. The article presents a research of the car-care service market in the town of Zima and Zima District. The substantiation of the basic development directions for the car service market is made on the basis of the data taken from RTD STSI of DIA of Zima and Zima District; the data that is freely available on the official website of the Federal Tax Service in the section on a Single Registry of Small Business Entities, collected by A.Yu. Ignatyev. The authors analyze the activities of the majority of car service companies located in the area investigated. The analysis resulted in identifying four
\end{abstract}

(C) А. Ю. Игнатьев, Н. А. Брянская, 2017

\section{Baikal Research Journal}


main companies operating on the market. The further analysis allows to reveal the competitors' strong and weak points and to determine the leader of this market. KEYWORDS. Car service companies; car services; car-care center; competitors; analysis; market.

ARTICLE INFO. Received July 3, 2017; accepted October 11, 2017; available online October 25, 2017.

В современное время, где каждый добивается своего места и старается удерживать позиции на рынке автосервисных услуг в условиях жесткой конкурентной борьбы, начинающему предпринимателю, стоит уделить особое внимание анализу уже действующих компаний, то есть подробно изучить потенциальных конкурентов на рынке услуг $[1$, с. 109]. Главными направлениями в подробном изучении конкурентов на рынке являются: вид деятельности, ассортимент предлагаемых услуг, стоимость услуг, список обслуживаемых клиентов, уровень известности автосервиса и другие [2, с. 167].

Ни один автосервис не сможет достичь над конкурентами абсолютного превосходства по всем показателям и характеристикам предоставляемых услуг и способам продвижения себя на рынке этих услуг. Важно расставить приоритеты и разработать стратегию, ориентируясь от происходящих ситуаций на рынке и стараться использовать сильные и слабые стороны действующих автосервисов. Конкурентная стратегия должна быть направлена на долгосрочные преимущества над конкурентами [3, с. 114].

Конкурентный анализ проводится с целью выявления характерных черт поведения конкурентов и их потенциальных возможностей улучшить свое положение на рынке автосервисных услуг ${ }^{1}$. Анализ конкурентов проводиться в два этапа:

1. Выявление лидеров в отрасли, с целью отождествления благоприятных возможностей и опасностей, с которыми может столкнутся автосервис в отрасли [4, c. 29].

2. Формулирование основных вариантов конкурентной стратегии, которые будет соответствовать ценовому лидерству, диапазону автосервисных услуг, фокусированию на рыночных нишах, разделению по качеству и технологии $[5$, с. 6$]$.

Город Зима и Зиминский район - это одно из административно-территориальных и муниципальных образований в Иркутской области Российской Федерации.

В самой городе Зима проживает 31283 и в Зиминском районе 13481 человек. Район составляет 12 сельских поселений. В настоящее время в Зиминском районе числится 41 населенный пункт. Районный центр - город Зима, от областного центра - г. Иркутска находится в 275,8 км по автомобильной дороге и в 251 км по железной дороге ${ }^{2}$. На территории города Зима и Зиминского района общей площадью 52,85 и 7,019 тыс. кв. км соответственно действует 18 автосервисных компаний из них в самом районном центре общей площадью 5285 га действует 15 автосервисов. Из них 5 компаний работают, не имея государственной регистрации ${ }^{3}$.

Автосервисные компании, работающие на исследуемой территории, по своей сути являются универсальными, предоставляющие широкий спектр услуг, осуществляют ремонт как российских, так и зарубежных автомобилей.

Анализ работающих автосервисов и видов их деятельности, позволяет разделить их на две группы: малые автосервисы и микро-автосервисы. Малые автосер-

\footnotetext{
${ }^{1}$ Особенности рынка автосервисных услуг, его сущность и структура. URL: http://lektsii.org/6104408.html.

${ }^{2}$ Википедия. Свободная энциклопедия. URL: https://ru.wikipedia.org/wiki/Зима_(город).

${ }^{3}$ Федеральная налоговая служба. Единый реестр субъектов малого и среднего предпринимательства. URL: https://rmsp.nalog.ru/search.html?mode=extended.
}

\section{Baikal Research Journal}


висы содержат в себе от трех до семи постов и предлагают следующий перечень услуг: кузовные, техническое-обслуживание, шиномонтажные, электрокарбюраторные, замена масла, ремонт ходовой части, экспрессдиагностику, а также продают запчасти и автопринадлежности [6, с. 27]. Микро-автоервисы - это автосервисы гаражного типа, содержащие в себе один-два поста [7, с. 105].

Автосервисные услуги по конкурентобразующим характеристикам делятся на следующие сегменты:

1. Индивидуальные мастера, работают сами на себя, независимы от каких-либо компаний, как правило, такие автосервисы не имеют регистрации [8, с. 26].

2. Компании общего назначения, предоставляют услуги по ремонту легковых автомобилей [9, с. 13$]$.

При проведении анализа рынка, были охарактеризованы 18 автосервисных компаний. Все организации находятся на одной территории и имеют равные условия для развития предпринимательской деятельности и направлены на клиентов со средним и низким уровнем дохода. Вся собранная информация о компаниях представлена в табл. 1 и 2.

В табл. 1 используются следующие сокращения: ИП — индивидуальный предприниматель, ТО и РЛА и ЛГАС - техническое обслуживание и ремонт легковых автомобилей и легких грузовых автотранспортных средств, ТО и $\mathrm{PAC}$ - техническое обслуживание и ремонт автотранспортных средств, ТРАДУ и $\Pi$ - торговля розничная автомобильными деталями, узлами и принадлежностями). Данные об особенностях работы автосервисных компаний представлены в табл. 2.

Охарактеризованные автором компании ориентированы на клиентов со средним и низким уровнем дохода. По статистическим данным среднедушевой денежный доход за 2017 г. составил 4563 р., для трудоспособного населения -15601 р., средняя заработная плата работников района составила 25486.1 p. $^{4}$ Поскольку среднедушевой доход и средняя заработная плата невысокие, все автосервисы региона предлагают примерно одинаковые цены на предоставляемые услуги.

Основной и дополнительный виды деятельности исследуемых компаний: техническое обслуживание и ремонт автотранспортных средств, розничная торговля автомобильными деталями, узлами и принадлежностями. Благодаря тому, что на территории анализируемых компаний имеется автомагазин, клиент экономит свое время на поиск запчастей в других автомагазинах.

В ходе изучения деятельности четырех основных конкурентов были выявлены их слабые стороны:

1. Не развита зона ожидания (отдыха), а для клиентов это имеет особое значение.

2. Не уделяется должного внимания скидкам на услуги и работы. Скидки предоставляет только автосервис «МБА» и то только постоянным клиентам и с согласия руководителя.

3. Отсутствует гарантия на выполняемые работы и услуги.

4. Неудобные подъезды к автосервису.

5. Имеет место несвоевременное выполнение заказов.

6. Качество предлагаемых услуг и обслуживание находится не на высоком уровне. Качество предлагаемых услуг в свою очередь зависит от оборудования, [10, с. 57]. Для выявления конкурентоспособности анализируемых компаний в работе было проведено сравнение используемого технического оборудования (см. табл. 3).

${ }^{4}$ Федеральная служба государственной статистики. URL: http://www.gks.ru/wps/wcm/connect/ rosstat_main/rosstat/ru/statistics/population/level/\#.

\section{Baikal Research Journal}

электронный научный журнал Байкальского государственного университета 
При сравнивании технического оборудования обнаружено, что автосервис «МБА» и автосервис «Ходовой» имеют в своем распоряжении технический большой парк оборудования. Наибольшая доля диагностического оборудования наблюдается у компаний «Ходовой» и «Авто Авангард», а это значит, что эти компании смогут в кратчайшие сроки определить неисправность без детальной разборки на узлы и агрегаты, что способствует сокращению времени на обслуживание. Передовое покрасочное оборудование стоит на вооружении в автосервисе МБА. У автосервиса «Авто Авангард» и «Ходовой» имеется хорошее пневматическое оборудование, при помощи этого инструмента облегчаются физически трудозатратные операции, тем самым улучшаются условия труда персонала.

В ходе проведенного исследования, были сопоставлены цены ремонта автомобилей отечественного и импортного производства, поскольку выбранные нами автосервисы являются универсальными занимаются ремонтом как отечественных так зарубежных автомобилей. Все цены устанавливаются в соответствии с нормативными актами. На базе имеющихся у автосервисов прайс-листов проведено сравнительное исследования цен (см. табл. 4) [9, с. 104].

Таблица 1

Организационно правовые формы автосервисных компаний в г. Зима и Зиминском районе на 01.04.2017 г.

\begin{tabular}{|c|c|c|c|c|}
\hline \multirow{2}{*}{$\begin{array}{c}\text { Наимено- } \\
\text { вание }\end{array}$} & \multirow{2}{*}{$\begin{array}{c}\text { Органи- } \\
\text { зационно } \\
\text { правовая } \\
\text { форма }\end{array}$} & $\begin{array}{c}\text { Категория } \\
\text { субъекта } \\
\text { малого } \\
\text { предпринима- } \\
\text { тельства }\end{array}$ & $\begin{array}{c}\text { Сведения о видах экономической деятельности } \\
\text { по общероссийскому классификатору видов }\end{array}$ \\
\cline { 4 - 5 } Мкономической деятельности
\end{tabular}

\section{Baikal Research Journal}


Окончание табл. 1

\begin{tabular}{|c|c|c|c|c|}
\hline \multirow{2}{*}{$\begin{array}{l}\text { Наимено- } \\
\text { вание }\end{array}$} & \multirow{2}{*}{$\begin{array}{l}\text { Органи- } \\
\text { зационно } \\
\text { правовая } \\
\text { форма }\end{array}$} & \multirow{2}{*}{$\begin{array}{c}\text { Категория } \\
\text { субъекта } \\
\text { малого пред- } \\
\text { принима- } \\
\text { тельства }\end{array}$} & \multicolumn{2}{|c|}{$\begin{array}{c}\text { Сведения о видах экономической деятельности } \\
\text { по общероссийскому классификатору видов } \\
\text { экономической деятельности }\end{array}$} \\
\hline & & & $\begin{array}{c}\text { сведения об основном } \\
\text { виде деятельности }\end{array}$ & $\begin{array}{c}\text { сведения о } \\
\text { дополнительных } \\
\text { видах деятельности } \\
\end{array}$ \\
\hline Автосервис & $\begin{array}{c}\text { нет } \\
\text { регистрации }\end{array}$ & $\begin{array}{c}\text { микро } \\
\text { предприятие }\end{array}$ & То и РAC & - \\
\hline $\begin{array}{l}\text { Автосервис } \\
\text { «МБА» }\end{array}$ & $\begin{array}{l}\text { юридическое } \\
\text { лицо }\end{array}$ & $\begin{array}{c}\text { малое } \\
\text { предприятие }\end{array}$ & ТРАДУ и П & $\begin{array}{c}\text { То и РАС, техническое } \\
\text { обслуживание } \\
\text { и ремонт мотоциклов } \\
\text { и мототранспорнных } \\
\text { средств }\end{array}$ \\
\hline $\begin{array}{l}\text { Автосервис } \\
\text { «Ходовой» }\end{array}$ & $\begin{array}{l}\text { юридическое } \\
\text { лицо }\end{array}$ & $\begin{array}{c}\text { микро } \\
\text { предприятие }\end{array}$ & ТРАДУ и П & То и РАC \\
\hline $\begin{array}{l}\text { Автосервис } \\
\text { «Ксенон 38» }\end{array}$ & ИП & $\begin{array}{c}\text { микро } \\
\text { предприятие }\end{array}$ & ТРАДУ и П & $\begin{array}{c}\text { деятельность } \\
\text { автомобильного } \\
\text { грузового } \\
\text { транспорта и услуги } \\
\text { по перевозкам }\end{array}$ \\
\hline Мастерская & $\begin{array}{c}\text { нет } \\
\text { регистрации }\end{array}$ & $\begin{array}{c}\text { микро } \\
\text { предприятие }\end{array}$ & То и РAC & - \\
\hline $\begin{array}{l}\text { Автосервис } \\
\text { «Автомиг» }\end{array}$ & ИП & $\begin{array}{c}\text { микро } \\
\text { предприятие }\end{array}$ & ТРАДУ и П & То и РАC \\
\hline $\begin{array}{l}\text { Автосервис } \\
\text { «ИнтерАвт» }\end{array}$ & ИП & $\begin{array}{c}\text { микро } \\
\text { предприятие }\end{array}$ & ТРАДУ и П & То и РАC \\
\hline Мастерская & $\begin{array}{c}\text { нет } \\
\text { регистрации }\end{array}$ & $\begin{array}{c}\text { микро } \\
\text { предприятие }\end{array}$ & То и РАC & - \\
\hline
\end{tabular}

Особенности работы автосервисных компаний в 2. Зима и Зиминском районе

Таблица 2 на 01.04.2017 2 .

\begin{tabular}{|c|c|c|c|c|c|c|c|}
\hline $\begin{array}{l}\text { Наимено- } \\
\text { вание }\end{array}$ & $\begin{array}{c}\text { Наличие } \\
\text { клиентской } \\
\text { зоны ожидания }\end{array}$ & $\begin{array}{c}\text { Режим } \\
\text { работы, } \\
\text { часов }\end{array}$ & $\begin{array}{c}\text { Количе- } \\
\text { ство рабо- } \\
\text { чих дней } \\
\text { в неделе }\end{array}$ & $\begin{array}{c}\text { Производ- } \\
\text { ственная } \\
\text { мощность } \\
\text { (количество } \\
\text { постов) } \\
\end{array}$ & $\begin{array}{c}\text { Пло- } \\
\text { щадь, } \\
\mathbf{M}^{2}\end{array}$ & Скидки & Гарантии \\
\hline $\begin{array}{l}\text { Мастер- } \\
\text { ская }\end{array}$ & нет & $\begin{array}{l}9: 00- \\
18: 00\end{array}$ & 7 & 2 поста & 64 & $\begin{array}{c}\text { не предо- } \\
\text { ставляются }\end{array}$ & $\begin{array}{c}\text { не предо- } \\
\text { ставляются }\end{array}$ \\
\hline $\begin{array}{l}\text { Автосер- } \\
\text { вис }\end{array}$ & нет & $\begin{array}{l}9: 00- \\
18: 00\end{array}$ & 7 & $\begin{array}{c}3 \text { поста, } \\
1 \text { шиномон- } \\
\text { тажный цех }\end{array}$ & 144 & $\begin{array}{c}\text { не предо- } \\
\text { ставляются }\end{array}$ & $\begin{array}{c}\text { не предо- } \\
\text { ставляются }\end{array}$ \\
\hline $\begin{array}{l}\text { Мастер- } \\
\text { ская }\end{array}$ & нет & $\begin{array}{l}9: 00- \\
18: 00\end{array}$ & 7 & 2 поста & 96 & $\begin{array}{c}\text { не предо- } \\
\text { ставляются }\end{array}$ & $\begin{array}{c}\text { не предо- } \\
\text { ставляются }\end{array}$ \\
\hline $\begin{array}{l}\text { Мастер- } \\
\text { ская }\end{array}$ & нет & $\begin{array}{c}10: 00- \\
18: 00 \\
\end{array}$ & 6 & 2 поста & 64 & $\begin{array}{c}\text { не предо- } \\
\text { ставляются }\end{array}$ & $\begin{array}{c}\text { не предо- } \\
\text { ставляются }\end{array}$ \\
\hline $\begin{array}{l}\text { Мастер- } \\
\text { ская }\end{array}$ & нет & $\begin{array}{c}10: 00- \\
21: 00\end{array}$ & 6 & 1 пост & 56 & $\begin{array}{c}\text { не предо- } \\
\text { ставляются }\end{array}$ & $\begin{array}{c}\text { не предо- } \\
\text { ставляются }\end{array}$ \\
\hline $\begin{array}{l}\text { Мастер- } \\
\text { ская }\end{array}$ & $\begin{array}{c}\text { соответствует } \\
\text { не по всем } \\
\text { параметрам }\end{array}$ & $\begin{array}{l}9: 00- \\
21: 00\end{array}$ & 6 & $\begin{array}{c}4 \text { поста, } \\
1 \text { шиномон- } \\
\text { тажный цех }\end{array}$ & 300 & $\begin{array}{c}\text { не предо- } \\
\text { ставляются }\end{array}$ & $\begin{array}{c}\text { не предо- } \\
\text { ставляются }\end{array}$ \\
\hline \begin{tabular}{|l|} 
Автосер- \\
вис и ши- \\
номонтаж \\
«Автосоло»
\end{tabular} & нет & $\begin{array}{l}9: 00- \\
18: 00\end{array}$ & 6 & 2 поста & 82 & $\begin{array}{c}\text { не предо- } \\
\text { ставляются }\end{array}$ & $\begin{array}{c}\text { не предо- } \\
\text { ставляются }\end{array}$ \\
\hline
\end{tabular}

\section{Baikal Research Journal}


Окончание табл. 2

\begin{tabular}{|c|c|c|c|c|c|c|c|}
\hline $\begin{array}{c}\text { Наимено- } \\
\text { вание }\end{array}$ & $\begin{array}{c}\text { Наличие кли- } \\
\text { ентской зоны } \\
\text { ожидания }\end{array}$ & $\begin{array}{c}\text { Режим } \\
\text { работы, } \\
\text { часов }\end{array}$ & $\begin{array}{c}\text { Количе- } \\
\text { ство рабо- } \\
\text { чих дней } \\
\text { в неделе }\end{array}$ & $\begin{array}{c}\text { Производ- } \\
\text { ственная } \\
\text { мощность } \\
\text { (количество } \\
\text { постов) } \\
\end{array}$ & $\begin{array}{l}\text { Пло- } \\
\text { щадь, } \\
\text { м }^{2}\end{array}$ & Скидки & Гарантии \\
\hline Автосервис & нет & $\begin{array}{l}9: 00- \\
18: 00\end{array}$ & 7 & $\begin{array}{c}2 \text { поста, } \\
1 \text { шиномон- } \\
\text { тажный цех }\end{array}$ & 160 & $\begin{array}{c}\text { не предо- } \\
\text { ставляются }\end{array}$ & $\begin{array}{c}\text { не предо- } \\
\text { ставляются }\end{array}$ \\
\hline $\begin{array}{l}\text { Автосер- } \\
\text { вис «Авто } \\
\text { Авангард» }\end{array}$ & нет & $\begin{array}{l}9: 00- \\
18: 00\end{array}$ & 7 & 1 поста & 48,8 & $\begin{array}{c}\text { не предо- } \\
\text { ставляются }\end{array}$ & $\begin{array}{c}\text { не предо- } \\
\text { ставляются }\end{array}$ \\
\hline $\begin{array}{l}\text { Автосе } \\
\text { рвис }\end{array}$ & $\begin{array}{c}\text { соответствует } \\
\text { не по всем } \\
\text { параметрам }\end{array}$ & $\begin{array}{l}9: 00- \\
18: 00\end{array}$ & 6 & 4 поста & 278 & $\begin{array}{c}\text { не предо- } \\
\text { ставляются }\end{array}$ & $\begin{array}{c}\text { не предо- } \\
\text { ставляются }\end{array}$ \\
\hline Автосервис & $\begin{array}{c}\text { нет соответ- } \\
\text { ствует }\end{array}$ & $\begin{array}{l}9: 00- \\
18: 00 \\
\end{array}$ & 7 & 1 пост & 24 & $\begin{array}{c}\text { не предо- } \\
\text { ставляются }\end{array}$ & $\begin{array}{c}\text { не предо- } \\
\text { ставляются }\end{array}$ \\
\hline $\begin{array}{l}\text { Авто- } \\
\text { сервис } \\
\text { «МБА» }\end{array}$ & $\begin{array}{c}\text { не по всем } \\
\text { параметрам }\end{array}$ & $\begin{array}{c}\Pi_{\mathrm{H}}-\Pi_{\mathrm{T}} \\
10: 00- \\
18: 00, \\
\text { Сб-Вc } \\
10: 00- \\
15: 00 \\
\end{array}$ & 7 & $\begin{array}{c}3 \text { поста, } \\
1 \text { покрасоч- } \\
\text { ный цех, } \\
1 \text { шиномон- } \\
\text { тажный цех }\end{array}$ & 256 & $\begin{array}{l}\text { предостав- } \\
\text { ляются } \\
\text { скидки по- } \\
\text { стоянным } \\
\text { клиентам }\end{array}$ & $\begin{array}{c}\text { не предо- } \\
\text { ставляются }\end{array}$ \\
\hline $\begin{array}{c}\text { Автосервис } \\
\text { «Ходовой» }\end{array}$ & $\begin{array}{c}\text { соответствует } \\
\text { не по всем } \\
\text { параметрам }\end{array}$ & $\begin{array}{c}\text { Пн-Пт } \\
10: 00- \\
18: 00, \\
\text { Сб-Вс } \\
10: 00- \\
15: 00 \\
\end{array}$ & 7 & 2 поста & 103 & $\begin{array}{l}\text { не предо- } \\
\text { ставляются }\end{array}$ & $\begin{array}{c}\text { не предо- } \\
\text { ставляются }\end{array}$ \\
\hline $\begin{array}{l}\text { Автосер- } \\
\text { вис «Ксе- } \\
\text { нон 38» }\end{array}$ & $\begin{array}{c}\text { соответствует } \\
\text { не по всем } \\
\text { параметрам }\end{array}$ & $\begin{array}{c}\Pi_{н}-\Pi_{\mathrm{T}} \\
10: 00- \\
18: 00, \\
\text { Сб-Вс } \\
10: 00- \\
15: 00\end{array}$ & 7 & 2 поста & 103 & $\begin{array}{c}\text { не предо- } \\
\text { ставляются }\end{array}$ & $\begin{array}{c}\text { не предо- } \\
\text { ставляются }\end{array}$ \\
\hline $\begin{array}{l}\text { Мастер- } \\
\text { ская }\end{array}$ & $\begin{array}{c}\text { соответствует } \\
\text { не по всем } \\
\text { параметрам }\end{array}$ & $\begin{array}{l}9: 00- \\
18: 00\end{array}$ & 6 & 4 поста & 276 & $\begin{array}{c}\text { не предо- } \\
\text { ставляются }\end{array}$ & $\begin{array}{c}\text { не предо- } \\
\text { ставляются }\end{array}$ \\
\hline $\begin{array}{l}\text { Автосервис } \\
\text { «Автомиг» }\end{array}$ & $\begin{array}{c}\text { соответствует } \\
\text { не по всем } \\
\text { параметрам }\end{array}$ & $\begin{array}{l}9: 00- \\
20: 00\end{array}$ & 7 & 1 пост & 30 & $\begin{array}{c}\text { не предо- } \\
\text { ставляются }\end{array}$ & $\begin{array}{c}\text { не предо- } \\
\text { ставляются }\end{array}$ \\
\hline \begin{tabular}{|c|} 
Автосервис \\
«ИнтерАвт»
\end{tabular} & нет & $\begin{array}{c}10: 00- \\
21: 00\end{array}$ & 6 & 6 постов & 200 & $\begin{array}{c}\text { не предо- } \\
\text { ставляются }\end{array}$ & $\begin{array}{c}\text { не предо- } \\
\text { ставляются }\end{array}$ \\
\hline $\begin{array}{l}\text { Мастер- } \\
\text { ская }\end{array}$ & нет & $\begin{array}{l}9: 00- \\
18: 00\end{array}$ & 6 & $\begin{array}{c}2 \text { поста, } \\
1 \text { шиномон- } \\
\text { тажный цех }\end{array}$ & 198 & $\begin{array}{c}\text { не предо- } \\
\text { ставляются }\end{array}$ & $\begin{array}{c}\text { не предо- } \\
\text { ставляются }\end{array}$ \\
\hline
\end{tabular}

Структура технологического оборудования исследуемых компаний

\begin{tabular}{|c|c|c|c|c|c|c|c|c|}
\hline \multirow[b]{2}{*}{$\begin{array}{c}\text { Автосервисное } \\
\text { оборудование }\end{array}$} & \multicolumn{2}{|c|}{$\begin{array}{c}\text { Автосервис } \\
\text { «МБА» }\end{array}$} & \multicolumn{2}{|c|}{$\begin{array}{l}\text { Автосервис } \\
\text { «Ходовой» }\end{array}$} & \multicolumn{2}{|c|}{$\begin{array}{l}\text { Автосервис } \\
\text { «Автосоло» }\end{array}$} & \multicolumn{2}{|c|}{$\begin{array}{c}\text { Автосервис «Авто } \\
\text { Авангард» }\end{array}$} \\
\hline & $\begin{array}{c}\text { баланс } \\
\text { стои- } \\
\text { мость, } \\
\text { тыс. р. }\end{array}$ & $\begin{array}{c}\text { удель- } \\
\text { ный } \\
\text { вес, \% }\end{array}$ & $\begin{array}{c}\text { баланс } \\
\text { стои- } \\
\text { мость, } \\
\text { тыс. р. }\end{array}$ & $\begin{array}{l}\text { удель- } \\
\text { ный } \\
\text { вес, \% }\end{array}$ & $\begin{array}{c}\text { баланс } \\
\text { стои- } \\
\text { мость, } \\
\text { тыс. p. }\end{array}$ & $\begin{array}{l}\text { удель- } \\
\text { ный } \\
\text { вес, \% }\end{array}$ & $\begin{array}{c}\text { баланс } \\
\text { стои- } \\
\text { мость, } \\
\text { тыс. р. }\end{array}$ & $\begin{array}{c}\text { удель- } \\
\text { ный вес, } \\
\%\end{array}$ \\
\hline $\begin{array}{l}\text { Производ- } \\
\text { ственно-техни- } \\
\text { ческое обору- } \\
\text { дование }\end{array}$ & 10 & 1 & 10 & 1 & 10 & 1 & 0 & 0,0 \\
\hline
\end{tabular}

\section{Baikal Research Journal}


Окончание табл. 3

\begin{tabular}{|c|c|c|c|c|c|c|c|c|}
\hline \multirow[b]{2}{*}{$\begin{array}{c}\text { Автосервисное } \\
\text { оборудование }\end{array}$} & \multicolumn{2}{|c|}{$\begin{array}{c}\text { Автосервис } \\
\text { «МБА» }\end{array}$} & \multicolumn{2}{|c|}{$\begin{array}{l}\text { Автосервис } \\
\text { «Ходовой» }\end{array}$} & \multicolumn{2}{|c|}{$\begin{array}{l}\text { Автосервис } \\
\text { «Автосоло» }\end{array}$} & \multicolumn{2}{|c|}{$\begin{array}{c}\text { Автосервис «Авто } \\
\text { Авангард» }\end{array}$} \\
\hline & $\begin{array}{l}\text { баланс } \\
\text { стои- } \\
\text { мость, } \\
\text { тыс. p. }\end{array}$ & $\begin{array}{l}\text { удель- } \\
\text { ный } \\
\text { вес, \% }\end{array}$ & $\begin{array}{c}\text { баланс } \\
\text { стои- } \\
\text { мость, } \\
\text { тыс. р. }\end{array}$ & $\begin{array}{l}\text { удель- } \\
\text { ный } \\
\text { вес, \% }\end{array}$ & $\begin{array}{c}\text { баланс } \\
\text { стои- } \\
\text { мость, } \\
\text { тыс. р. }\end{array}$ & $\begin{array}{l}\text { удель- } \\
\text { ный } \\
\text { вес, \% }\end{array}$ & $\begin{array}{c}\text { баланс } \\
\text { стои- } \\
\text { мость, } \\
\text { тыс. р. }\end{array}$ & $\begin{array}{c}\text { удель- } \\
\text { ный вес, } \\
\%\end{array}$ \\
\hline $\begin{array}{l}\text { Гидравличе- } \\
\text { ский инстру- } \\
\text { мент }\end{array}$ & 50 & 3 & 50 & 6 & 30 & 4 & 30 & 10 \\
\hline $\begin{array}{l}\text { Пневматиче- } \\
\text { ское оборудо- } \\
\text { вание } \\
\end{array}$ & 110 & 8 & 120 & 15 & 90 & 14 & 70 & 24 \\
\hline $\begin{array}{l}\text { Диагностиче- } \\
\text { ское оборудо- } \\
\text { вание }\end{array}$ & 172,6 & 12 & 160 & 20 & 90 & 14 & 50 & 17 \\
\hline $\begin{array}{l}\text { Заправочное } \\
\text { и смазочное } \\
\text { оборудование } \\
\end{array}$ & 61 & 4 & 59,8 & 8 & 40 & 6 & 29 & 10 \\
\hline $\begin{array}{l}\text { Шиномонтаж- } \\
\text { ное оборудо- } \\
\text { вание }\end{array}$ & 0 & 0 & 0 & 0 & 262,6 & 40 & 0 & 0,0 \\
\hline $\begin{array}{l}\text { Спец инстру- } \\
\text { мент для } \\
\text { авторемонта } \\
\text { (съемники) }\end{array}$ & 25 & 2 & 20 & 3 & 15 & 12 & 20 & 7 \\
\hline $\begin{array}{l}\text { Подъемное } \\
\text { оборудование }\end{array}$ & 305,8 & 21 & 260 & 33 & 100 & 15 & 30 & 10 \\
\hline $\begin{array}{l}\text { Покрасочное } \\
\text { оборудование }\end{array}$ & 600 & 41 & 0 & 0,0 & 0 & 0,0 & 0 & 0,0 \\
\hline $\begin{array}{l}\text { Моечное } \\
\text { и клининговое } \\
\text { оборудование }\end{array}$ & 91,6 & 6 & 50 & 6 & 0 & 0,0 & 0 & \\
\hline Прочее & 35 & 2 & 66 & 8 & 25 & 4 & 65 & 22 \\
\hline Итого & 1461 & 100 & 785,8 & 100 & 662,6 & 100 & 294 & 100 \\
\hline
\end{tabular}

"Разработано автором.

Таблица 4

Сравнение иен на услуги по релонту и ТО отечественных и зарубежных автомобилей по состоянию на 01.04.2017 г., p.

\begin{tabular}{|c|c|c|c|c|c|c|c|c|}
\hline \multirow{2}{*}{$\begin{array}{c}\text { Перечень услуг по } \\
\text { ремонту легковых } \\
\text { автомобилей }\end{array}$} & \multicolumn{2}{|c|}{$\begin{array}{c}\text { Автосервис } \\
\text { «МБА» }\end{array}$} & \multicolumn{2}{|c|}{$\begin{array}{c}\text { Автосервис } \\
\text { «Ходовой» }\end{array}$} & \multicolumn{2}{|c|}{$\begin{array}{l}\text { Автосервис } \\
\text { «Автосоло» }\end{array}$} & \multicolumn{2}{|c|}{$\begin{array}{c}\text { Автосервис } \\
\text { «Авто } \\
\text { Авангард» }\end{array}$} \\
\hline & $\begin{array}{c}\text { отече- } \\
\text { ствен- } \\
\text { ные }\end{array}$ & $\begin{array}{c}\text { ино- } \\
\text { марки }\end{array}$ & $\begin{array}{c}\text { отече- } \\
\text { ствен- } \\
\text { ные } \\
\end{array}$ & $\begin{array}{c}\text { иномар- } \\
\text { ки }\end{array}$ & $\begin{array}{l}\text { отече- } \\
\text { стве- } \\
\text { нные }\end{array}$ & $\begin{array}{c}\text { ино- } \\
\text { марки }\end{array}$ & $\begin{array}{c}\text { отече- } \\
\text { ствен- } \\
\text { ные } \\
\end{array}$ & $\begin{array}{l}\text { иномар- } \\
\text { ки }\end{array}$ \\
\hline $\begin{array}{l}\text { Замена лобового стек- } \\
\text { ла }\end{array}$ & от 600 & $\begin{array}{l}500- \\
4000\end{array}$ & От 500 & $\begin{array}{c}\text { Oт } \\
10000\end{array}$ & $\begin{array}{l}\text { Oт } \\
250\end{array}$ & От 300 & От 300 & От 350 \\
\hline $\begin{array}{l}\text { Компьютерная } \\
\text { диагностика двигателя }\end{array}$ & $\begin{array}{l}500- \\
1000\end{array}$ & $\begin{array}{l}500- \\
1000\end{array}$ & $\begin{array}{l}500- \\
1000\end{array}$ & $\begin{array}{l}500- \\
1000\end{array}$ & $\begin{array}{l}450- \\
1500\end{array}$ & $\begin{array}{l}450- \\
1500\end{array}$ & $\begin{array}{l}500- \\
1000\end{array}$ & $\begin{array}{l}500- \\
1000\end{array}$ \\
\hline Замена ремня ГРМ & $\begin{array}{l}500- \\
1800\end{array}$ & $\begin{array}{l}2500- \\
15000\end{array}$ & $\begin{array}{l}500- \\
2000\end{array}$ & $\begin{array}{l}3000- \\
15000\end{array}$ & $\begin{array}{l}\text { От } 1 \\
000\end{array}$ & $\begin{array}{l}\text { От } \\
3000\end{array}$ & $\begin{array}{l}500- \\
2000\end{array}$ & $\begin{array}{c}\text { От } \\
3000\end{array}$ \\
\hline Развал-схождение & $\begin{array}{l}700- \\
1000\end{array}$ & $\begin{array}{l}500- \\
1000\end{array}$ & $\begin{array}{l}500- \\
1000\end{array}$ & $\begin{array}{l}600- \\
1000\end{array}$ & $\begin{array}{l}500- \\
1000\end{array}$ & $\begin{array}{l}700- \\
1000\end{array}$ & $\begin{array}{l}500- \\
1200\end{array}$ & $\begin{array}{l}700- \\
1200\end{array}$ \\
\hline $\begin{array}{l}\text { Замена топливного на- } \\
\text { соса (электрического) }\end{array}$ & $\begin{array}{l}600- \\
3000 \\
\end{array}$ & $\begin{array}{c}1000- \\
3000 \\
\end{array}$ & От 500 & $\begin{array}{l}900- \\
2800\end{array}$ & $\begin{array}{l}500- \\
2500\end{array}$ & \begin{tabular}{|c|c|} 
Oт \\
1000 \\
\end{tabular} & $\begin{array}{l}500- \\
2500\end{array}$ & $\begin{array}{c}1500- \\
3000 \\
\end{array}$ \\
\hline
\end{tabular}

\section{Baikal Research Journal}


Окончание табл. 4

\begin{tabular}{|c|c|c|c|c|c|c|c|c|}
\hline \multirow{2}{*}{$\begin{array}{c}\text { Перечень услуг по } \\
\text { ремонту легковых } \\
\text { автомобилей }\end{array}$} & \multicolumn{2}{|c|}{$\begin{array}{c}\text { Автосервис } \\
\text { «МБА» }\end{array}$} & \multicolumn{2}{|c|}{$\begin{array}{l}\text { Автосервис } \\
\text { «Ходовой» }\end{array}$} & \multicolumn{2}{|c|}{$\begin{array}{l}\text { Автосервис } \\
\text { «Автосоло» }\end{array}$} & \multicolumn{2}{|c|}{$\begin{array}{c}\text { Автосервис } \\
\text { «Авто } \\
\text { Авангард» }\end{array}$} \\
\hline & $\begin{array}{c}\text { отече- } \\
\text { ствен- } \\
\text { ные }\end{array}$ & $\begin{array}{c}\text { ино- } \\
\text { марки }\end{array}$ & $\begin{array}{l}\text { отече- } \\
\text { ствен- } \\
\text { ные }\end{array}$ & $\begin{array}{c}\text { иномар- } \\
\text { ки }\end{array}$ & $\begin{array}{l}\text { отече- } \\
\text { стве- } \\
\text { нные } \\
\end{array}$ & $\begin{array}{c}\text { ино- } \\
\text { марки }\end{array}$ & $\begin{array}{c}\text { отече- } \\
\text { ствен- } \\
\text { ные } \\
\end{array}$ & $\begin{array}{l}\text { иномар- } \\
\text { ки }\end{array}$ \\
\hline $\begin{array}{l}\text { Замена } \\
\text { рулевой рейки }\end{array}$ & $\begin{array}{l}\text { От } 1 \\
500\end{array}$ & $\begin{array}{c}2500- \\
9000\end{array}$ & $\begin{array}{c}\text { От } \\
1500\end{array}$ & $\begin{array}{c}3000- \\
9000\end{array}$ & $\begin{array}{l}\text { От } 1 \\
200\end{array}$ & $\begin{array}{l}2500- \\
10000\end{array}$ & $\begin{array}{l}1500- \\
3000\end{array}$ & $\begin{array}{c}\mathrm{OT}_{\mathrm{T}} \\
2500\end{array}$ \\
\hline $\begin{array}{l}\text { Замена масла } \\
\text { в двигателе }\end{array}$ & $\begin{array}{l}200- \\
1000 \\
\end{array}$ & $\begin{array}{l}200- \\
1500 \\
\end{array}$ & $\begin{array}{l}300- \\
1000 \\
\end{array}$ & $\begin{array}{l}300- \\
1500 \\
\end{array}$ & $\begin{array}{c}\text { От } \\
300 \\
\end{array}$ & $\begin{array}{l}300- \\
1500 \\
\end{array}$ & $\begin{array}{l}250- \\
1000 \\
\end{array}$ & $\begin{array}{l}250- \\
1500 \\
\end{array}$ \\
\hline $\begin{array}{l}\text { Замена тормозных } \\
\text { колодок }\end{array}$ & $\begin{array}{c}200- \\
400\end{array}$ & $\begin{array}{l}400- \\
1500\end{array}$ & $\begin{array}{c}200- \\
500\end{array}$ & $\begin{array}{l}350- \\
1500\end{array}$ & $\begin{array}{c}250- \\
500\end{array}$ & $\begin{array}{l}500- \\
2000\end{array}$ & От 300 & От 500 \\
\hline $\begin{array}{l}\text { Окраска бокового эле- } \\
\text { мента(дверь, бампер) }\end{array}$ & $\begin{array}{c}5500- \\
7500\end{array}$ & $\begin{array}{c}5550- \\
7500\end{array}$ & $\begin{array}{c}\text { Oт } \\
6000\end{array}$ & $\begin{array}{l}\text { OT } \\
6000\end{array}$ & $\begin{array}{l}\text { От } 5 \\
000\end{array}$ & $\begin{array}{l}5000- \\
8000\end{array}$ & $\begin{array}{l}\text { Oт } \\
5500\end{array}$ & От 5500 \\
\hline $\begin{array}{l}\text { Замена } \\
\text { лампочек }\end{array}$ & $\begin{array}{l}50- \\
1000\end{array}$ & $\begin{array}{l}50- \\
1000\end{array}$ & $\begin{array}{l}100- \\
1000\end{array}$ & $\begin{array}{l}100- \\
1000\end{array}$ & $\begin{array}{c}60- \\
1000\end{array}$ & $\begin{array}{l}50- \\
1200\end{array}$ & От 50 & От 50 \\
\hline
\end{tabular}

* Разработано автором.

От того насколько востребована предлагаемая услуга зависит стоимость на эту услугу. В ходе общения с руководством и работниками автосервисов автор сделал вывод, что самые востребованные услуги - это ремонт кузова, подвески и электрооборудования. На спрос влияет, с какой интенсивностью используется автомобиль, временя года, условия хранения и периодичность технических осмотров [11, с 26].

Приобретать оборудование надо в зависимости от того, какие услуги необходимы автомобилистам.

В результате исследования процесса обслуживания автосервисных компаний Зимы и Зиминского района установлено, что они предлагают услуги и работы по техническому обслуживанию, ремонту, продаже запчастей и имеют простую схему организации обслуживания.

Конкурентоспособность анализируемых компаний определилась, по рейтинговой оценке, представленной в табл. 5. Наибольшая оценка коэффициента конкурентоспособности выявлена автосервисов «Ходовой» и «МБА». Уровень этого показателя у автосервиса «Автосоло» и автосервиса «Авто Авангард» ниже.

Таблица 5

Рейтинговая оценка конкурентоспособности автосервисных колпаний, ед.

\begin{tabular}{|l|c|c|c|c|}
\hline \multicolumn{1}{|c|}{ Признак } & $\begin{array}{c}\text { Автосервис } \\
\text { «МБА» }\end{array}$ & $\begin{array}{c}\text { Автосервис } \\
\text { «Ходовой» }\end{array}$ & $\begin{array}{c}\text { Автосервис } \\
\text { «Автосоло» }\end{array}$ & $\begin{array}{c}\text { Автосервис } \\
\text { «Авто Авангард» }\end{array}$ \\
\hline Доступность цен & 4 & 3 & 5 & 4 \\
\hline Соблюдение сроков ремонта & 3 & 4 & 3 & 4 \\
\hline Широкий ассортимент услуг & 4 & 4 & 4 & 4 \\
\hline $\begin{array}{l}\text { Наличие современного обо- } \\
\text { рудования }\end{array}$ & 4 & 4 & 4 & 4 \\
\hline $\begin{array}{l}\text { Доброжелательное и вежли- } \\
\text { вое отношение }\end{array}$ & 5 & 4 & 4 & 3 \\
\hline Удобный подъезд & 3 & 4 & 3,6 & 3,6 \\
\hline $\begin{array}{l}\text { Коэффициент конкуренто- } \\
\text { способности }\end{array}$ & 3,8 & 3,8 & & 4 \\
\hline
\end{tabular}

\section{Baikal Research Journal}


В Зиминском районе наблюдается рост зарегистрированных автомобилей. Динамика прироста отображена на основе предоставленных данных РЭО ГИБДД ОВД по г. Зима и Зиминскому району (см. табл. 6). На основании прироста построен прогноз с положительной динамикой (см. рис 1). Прогноз среднего суточного количества обращений в автосервис показан на рис. 2 .

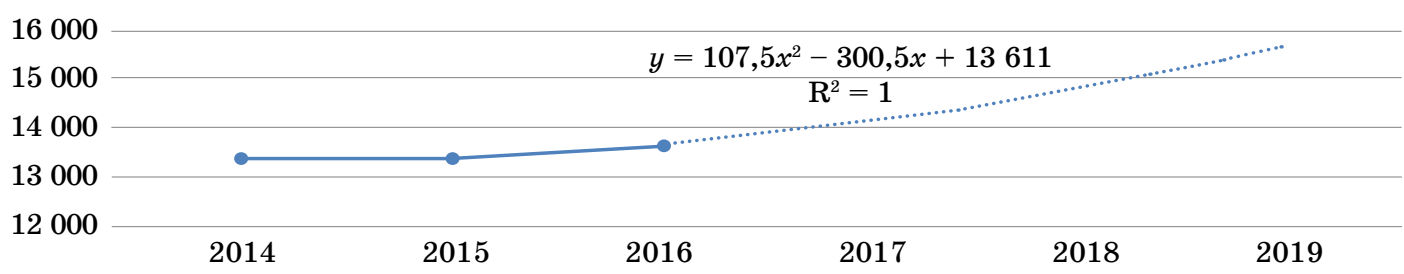

Рис. 1. Схема прогнозирования изменения размера парка в Зиминском районе на 3 г., 2017-2019 г2.

Таблица 6

Количество зарегистрированных автомобилей в Зиминском районе, ед.

\begin{tabular}{|l|r|r|r|}
\hline \multicolumn{1}{|c|}{ Категория автомобилей } & \multicolumn{1}{c|}{2014} & \multicolumn{1}{c|}{2015} & \multicolumn{1}{c|}{2016} \\
\hline Иностранные & 5836 & 6052 & 6119 \\
\hline Иностранные отечественного производства & 2280 & 2146 & 1963 \\
\hline Отечественные & 5302 & 5242 & 5595 \\
\hline Итого & 13418 & 13440 & 13677 \\
\hline
\end{tabular}

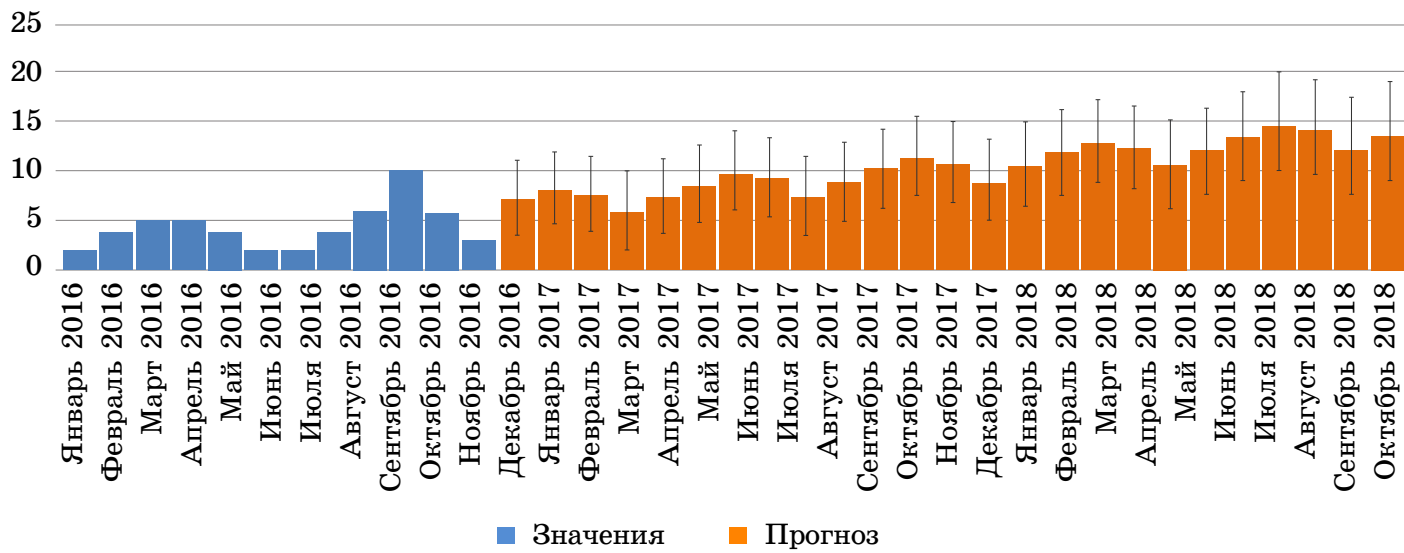

Рис. 2. Прогнозирование среднего суточного количества обращений в автосервис «МБА» по периодам на 2017-2018 г2.

Из выше изложенного можно сделать следующие выводы:

1. В связи с ростом автопарка в г. Зима и Зиминском районе спрос на услуги автосервиса будет только расти.

2. Компании, присутствующие на рынке не знают, на каком уровне они сейчас находятся и к чему надо стремиться. Конкурентоспособность автосервисных компаний не анализируется должным образом из-за отсутствия профессиональных работников.

\section{Baikal Research Journal}




\section{Список использованной литературы}

1. Стрекалова Н. Д. Бизнес-планирование: теория и практика : для бакалавров и специалистов / Н. Д. Стрекалова. - СПб. : ПИТЕР, 2013. - 352 с.

2. Разумовская А. Маркетинг услуг: настольная книга российского маркетолога-практика / А. Разумовская, В. Янченко. - М. : Вершина, 2006. - 476 с.

3. Азоев Г. Л. Конкуренция: анализ, стратегия и практика / Азоев Г. Л. - М. : Центр экономики и маркетинга, 2008. - 220 с.

4. Волгин В. В. Автосервис. Маркетинг и анализ: практ. пособие / В. В. Волгин. - 5-е изд., перераб. и доп. - М. : Дашков и К, 2010. - 671 с.

5. Пеньшин Н. В. Конкурентоспособность услуг автомобильного транспорта в условиях посткризисной модернизации экономики России / Н. В. Пеньшин. - Тамбов: Изд-во Тамб. гос. техн. ун-та, 2010. -156 с.

6. Дубровкий Д. А. Открываем автосервис: с чего начать, как преуспеть: советы владельцам и управляющим / Д. А. Дубровский. - СПб. : ПИТЕР, 2011. -249 с.

7. Кильдеева Р. А. Составление бизнес-плана предприятия. теория и практика: учебное пособие / Р. А. Кильдеева. - Петропавловск-Камчатский : КамчатГТУ, 2005. - 150 с.

8. Волгин В. В. Автосервис: структура и персонал : практическое пособие / В. В. Волгин. - 5-е изд., перераб. и доп. - М. : Дашков и К, 2010. - 406 с.

9. Управление автосервисом: учебное пособие для вузов / под общ. ред. Л. Б. Миротина. - М. : Экзамен, 2004. - 320 с.

10. Шуплецов, А. Ф. Бизнес-план фирмы. Рекомендации по разработке и анализу бизнес-проектов : учеб. пособие / А. Ф. Шуплецов. - Иркутск : Изд-во БГУЭП, 2004. - 165 с.

11. Сфера услуг: экономика, менеджмент, маркетинг. Практикум: учебное пособие / под ред. Т. Д. Бурменко. - М. : КНОРУС, 2016. - 422 с.

\section{References}

1. Strekalova N. D. Biznes-planirovanie: teoriya i praktika : dlya bakalavrov $i$ spetsialistov [Business planning: theory and practice: for bachelors and specialists]. Saint Petersburg, PITER Publ., 2013. $352 \mathrm{p}$.

2. Razumovskaya A., Yanchenko V. Marketing uslug: nastol'naya kniga rossiiskogo marketologa-praktika [Marketing of services: a table book of Russian practical marketer]. Moscow, Vershina Publ., 2006. 476 p.

3. Azoev G. L. Konkurentsiya: analiz, strategiya i praktika [Competition: analysis, strategy and practice]. Moscow, Tsentr ekonomiki i marketinga Publ., 2008. 220 p.

4. Volgin V. V. Avtoservis. Marketing i analiz: prakt. posobie [Car-care service. Marketing and analysis: a study guide]. $5^{\text {nd }}$ ed. Moscow, Dashkov i K Publ., 2010. $671 \mathrm{p}$.

5. Pen'shin N. V. Konkurentosposobnost' uslug avtomobil'nogo transporta $v$ usloviyakh postkrizisnoi modernizatsii ekonomiki Rossii [Competiveness of car services in terms of post-crisis modernization of Russia's economy]. Tambov state technical University Publ., 2010. 156 p.

6. Dubrovkii D. A. Otkryvaem avtoservis: s chego nachat', kak pre-uspet': sovety vladel'tsam $i$ upravlyayushchim [We're opening a car-care business: what to begin with, how to succeed: advice to car owners and managers]. Saint Petersburg, PITER Publ., 2011. 249 p.

7. Kil'deeva R. A. Sostavlenie biznes-plana predpriyatiya. teoriya i praktika: uchebnoe posobie [Provision of a company's business plan. Theory and practice: a study guide]. Petropavlovsk-Kamchatsky state technical University Publ., 2005. 150 p.

8. Volgin V. V. Avtoservis: struktura i personal : prakticheskoe posobie [Car service: structure and personnel: practical study guide]. $5^{\text {nd }}$ ed. Moscow, Dashkov i K Publ., 2010. $406 \mathrm{p}$.

9. Mirotina L. B. (ed.). Upravlenie avtoservisom: uchebnoe posobie dlya vuzov [Car service management: a university study guide]. Moscow, Ekzamen Publ., 2004. 320 p.

10. Shupletsov A. F. Biznes-plan firmy. Rekomendatsii po raz-rabotke $i$ analizu biznesproektov : ucheb. Posobie [Company's business plan. Recommendations on development and analysis of business projects: a study guide]. Irkutsk, Baikal State University of Economics and Law Publ., 2004. 165 p.

11. Burmenko T. D. (ed.). Sfera uslug: ekonomika, menedzhment, marketing. Praktikum: uchebnoe posobie [Service sector: economy, management, marketing. Case study: a study guide]. Moscow. KNORUS Publ., 2016. 422 p.

\section{Baikal Research Journal}




\section{Информация об авторах}

Игнатьев Алексей Юрьевич - студент, Байкальский государственный университет, 664003, г. Иркутск, ул. Ленина, 11, e-mail: ignatev-aleksei@mail.ru.

Брянская Наталья Александровна - кандидат экономических наук, доцент кафедры экономики предприятий и предпринимательской деятельности, Байкальский государственный университет, 664003, г. Иркутск, ул. Ленина, 11, e-mail: natalya_bryanskaya@mail.ru.

\section{Authors}

Aleksey Yu. Ignatyev - Student, Baikal State University, 11 Lenin St., 664003, Irkutsk; e-mail: ignatev-aleksei@mail.ru.

Natalya A. Bryanskaya - PhD in Economics, Associate Professor, Chair of Economy of Enterprises and Business Activity, Baikal State University, 11 Lenin St., 664003, Irkutsk; e-mail: natalya_bryanskaya@mail.ru.

\section{Для цитирования}

Игнатьев А. Ю. Анализ рынка автосервисных услуг в городе Зима и Зиминском районе / А. Ю. Игнатьев, Н. А. Брянская // Baikal Research Journal. - 2017. — T. 8, № 3. - DOI: 10.17150/2411-6262.2017.8(3).5.

\section{For citation}

Ignatyev A.Yu., Bryanskaya N. A. Analysis of car-care service market in the town of Zima and Zima District. Baikal Research Journal, 2017, vol. 8, no. 3. DOI: 10.17150/24116262.2017.8(3).5. (In Russian).

\section{Baikal Research Journal}

